\title{
Implementasi Sistem Cerdas Pada Gedung Workshop Otomasi Industri Balai Latihan Kerja Banda Aceh sebagai Solusi dalam Penghematan Energi Listrik
}

\author{
Muhammad Yusuf ${ }^{1 *}$ dan Ira Devi Sara ${ }^{2}$ \\ ${ }^{1}$ Jurusan Teknik Listrik, Balai Latihan Kerja Industri Kemnaker RI Banda Aceh, Aceh, Indonesia \\ ${ }^{2}$ Magister Teknik Elektro, Fakultas Teknik, Universitas Syiah Kuala, Banda Aceh, Aceh, Indonesia \\ *Corresponding author, e-mail: usoef@yahoo.co.id
}

\begin{abstract}
Abstrak Peningkatan konsumsi energi listrik bukan hanya terjadi di sektor industri dan rumah tangga tetapi juga terjadi di sektor perkantoran pemerintah. Pemerintah melalui peraturan Menteri ESDM No. 13 tahun 2012 menuntut penghematan pemakaian energi listrik. Balai Latihan Kerja Industri Banda Aceh merupakan salah satu gedung yang memperhatikan penghematan energi listrik tersebut. Pada penelitian ini dirancang sebuah sistem cerdas yang dapat mengendalikan penggunaan peralatan listrik untuk dapat mengefesienkan biaya penggunaan. Pengendalian dilakukan menggunakan programmable logic controller (PLC). Masukan dari sistem adalah sensor PIR, sensor asap, sensor ketinggian air, sensor fotocell, saklar, tombol darurat, tombol buka pintu utama dan sensor jendela. Peralatan yang dikendalikan terdiri dari empat pendingin ruangan, lima belas lampu, satu pompa air, kunci pintu utama, alarm dan telepon. Peralatan dikendalikan dengan metode on/off dimana PLC menganalisa sinyal input kemudian mengatur keadaan output sesuai dengan kondisi yang telah ditentukan berdasarkan kontrol program sistem cerdas yang telah deprogram pada PLC. Sistem telah berhasil mengendalikan peralatan secara efisien sehingga diperoleh penghematan penggunaan energy listrik. Balai Latihan Kerja Banda Aceh dapat menekan penghematan pembayaran rekening pemakaian energi listrik sebesar Rp. 11.398.962,-Berdasarkan biaya yang dikeluarkan untuk membuat sistem dan efisiensi yang dihasilkan, maka modal dapat dikembalikan dalam rentang waktu kurang dari tujuh bulan. Dengan diimplementasikan sistem cerdas penghematan pemakaian energi listrik yang dicanangkan dalam peraturan pemerintah dapat direalisasikan.
\end{abstract}

Kata Kunci : Sistem cerdas, PLC dan Penghematan

\begin{abstract}
The increase in electricity consumption does not only occur in the industrial and household sectors but also in the government office sector. The government through the Minister of Energy and Mineral Resources regulation No. 13 of 2012 demands savings in electricity usage. Balai Latihan Kerja Industri Banda Aceh is a building managed by considering the efficiency of electricity. In this research, a smart system that can control the use of equipment is designed to be able to streamline usage costs. System was controlled using a Programmable Logic Control (PLC). Input for the system are a PIR sensor, a smoke detector, a water level sensor, a photocell sensor, switch, emergency button, door lock, and window sensor. The controlled equipment consists of four air conditioners, fifteen lights, a water pump, main door lock, alarm, and telephone. The system is controlled by on/off method, PLC analyzes the input signal and then adjusts the output state according to the conditions specified based on the control program. The results shows that this system succeeded in controlling equipment efficiently. Management can reduce the electricity accounts by Rp. 11.398.962,- in a year. The payback period is less seven months. The implementation of a smart system in Balai Latihan Kerja Industri Banda Aceh for electricity efficiency can support government programs for energy sustainability.
\end{abstract}

Keywords : Electric power, smart systems, PLC,efficiency

\section{Pendahuluan}

Perkembangan teknologi tidak terlepas dengan penggunaan energi listrik. Energi listrik dapat diubah menjadi berbagai macam energi lainnya menggunakan peralatan-peralatan, seperti pengatur suhu atau Air Conditioner (AC), lampu, alarm, dan lain-lain. Pada akhirnya, penggunaan 
berbagai macam peralatan listrik tersebut akan semakin mendorong meningkatnya konsumsi energi listrik.

Meningkatnya konsumsi energi listrik bukan hanya terjadi di sektor industri dan rumah tangga tetapi juga terjadi di sektor perkantoran. Balai Latihan Kerja Banda Aceh merupakan salah satu perkantoran milik pemerintah dibawah Kementerian Ketenagakerjaan Republik Indonesia yang mempunyai peran melatih dan meningkatkan kompetensi tenaga kerja. Balai Latihan Kerja ini memilki kejuruan-kejuruan dan peralatanperalatan berstandar industri seperti pada kejuruan Teknik Listrik sub kejuruan Otomasi Industri yang banyak menggunakan motor listrik, pendingin ruangan dan beban-beban listrik berstandar industri lainnya sehingga tidak terlepas dengan penggunaan energi listrik yang besar tentunya.

Pemerintah melalui peraturan Menteri ESDM No. 13 tahun 2012 menuntut penghematan pemakaian energi listrik. Peraturan tersebut dengan jelas menyampaikan bahwa seluruh bangunan gedung kantor pemerintah baik di pusat maupun daerah harus melaksanakan program penghematan energi listrik pada sistem tata udara (Air Conditioner), sistem tata cahaya dan peralatan pendukung lainnya [1]. Hal ini menjadi perhatian bersama termasuk di Balai Latihan Kerja Industri Banda Aceh. Selama ini penggunaan sistem tata udara, sistem tata cahaya dan peralatan pendukung belum terkontrol dengan baik. Hal ini disebabkan karena beberapa faktor seperti kelupaan dan pola hidup manusia yang tidak peduli terhadap penghematan energi listrik.

Untuk mewujudkan penghematan energi listrik, pemantauan konsumsi atau manajemen energi listrik seperti pengontrolan penggunaan daya harus diterapkan secara efektif [2], [3] dengan tetap menjaga keseimbangan antara kenyamanan pengguna dan kebutuhan energi sehingga pengguna dapat mencapai tingkat kenyamanan yang diinginkan dengan jumlah konsumsi energi minimum [4], [5]. Penerapan manajemen energi listrik secara efektif dapat terlaksana jika sistem kontrol dengan cara konvensional yaitu dengan cara menyalakan dan mematikan beban-beban listrik melalui saklar manual digantikan dengan sistem cerdas, dikarenakan sistem konvensional dapat membatasi upaya penghematan energi listrik [6]. Sistem cerdas mampu memberikan kenyamanan yang lebih baik, keselamatan dan keamanan yang lebih terjamin serta dapat menghemat penggunaan energi listrik [7] sehingga dirancang sistem cerdas yang dapat mengatur dan mengontrol penggunaan daya seperti tata udara (Air Conditioner), tata cahaya (penerangan) dan mesin pompa air sesuai kebutuhan berbasis pada programmable logic controller (PLC), dengan adanya sisem ini pengunaan energi listrik dapat dikendalikan secara efisien yaitu tepat guna sesuai kebutuhan akan energi listrik [8]. Dalam penerapan teknologi untuk penghematan energi listrik ini, aspek ekonomi juga perlu diperhatikan seperti biaya investasi awal dan waktu pengembalian biaya investasi agar dapat diketahui kelayakan teknologi yang dimplementasikan [9], [10].

\section{Kontroler Elektronik}

\subsection{PLC Omron Sysmac CPM1A}

Pada perancangan sistem cerdas ini menggunakan PLC Omron Sysmac CPM1A sebagai alat kontrol yang dapat diprogram yang merupakan salah satu produk PLC dari Omron yang terbaru. CPM1 A merupakan PLC tipe paket yang tersedia dengan 10, 20,30,40 buah I/O (input/output). Sistem input outputnya berupa bit. Atau lebih dikenal dengan PLC tipe relay karena hanya membaca masukan dan menghasilkan keluaran dengan logika 1 atau 0 .

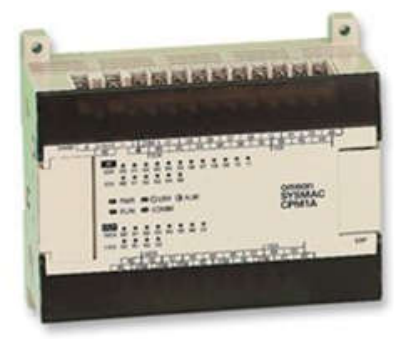

Gambar 1 PLC Omron Sysmac CPM1A 30 I/O [11]

Sebagaimana terlihat pada Gambar 1, PLC ini memiliki 30 terminal yang terdiri dari 18 terminal input dan 12 terminal output. Power supply yang dipakai berupa tegangan DC sehingga diperlukan sebuah trafo dalam penggunaannya [12].

Prinsip kerja dari PLC secara umum adalah PLC menerima sinyal-sinyal analog dari peralatan input luar seperti tombol, saklar, overload dan sensor-sensor lainnya. Sinyal analog ini oleh modul input akan dirubah menjadi sinyal digital Sinyal digital ini akan diolah oleh unit pemproses utama yaitu "Central Processing Unit " ( CPU ), sesuai dengan perintah program yang telah 
ditetapkan atau diprogram pada memori. Selanjutnya CPU akan mengambil keputusankeputusan yang kemudian akan dipindahkan ke modul output masih berupa sinyal-sinyal digital.

Modul output akan merubah sinyal-sinyal digital menjadi sinyal-s analog. Sinyal-sinyal analog inilah yang menggerakkan relay-relay atau kontaktor, yang merupakan peralatan output luar. Peralatan output luar ini yang nantinya akan menggerakkan mesin - mesin atau sistem yang dikontrolnya.

\subsection{Passive Infrared (PIR)}

PIR merupakan salah satu sensor yang menggunakan infrared untuk mendeteksi suatu benda. PIR berbeda dengan Infrared LED (Light Emiting Diode), Infrared LED dapat memancarkan cahaya namun tidak pada sensor PIR [13]. PIR sensor terdiri dari dua elemen sensing yang terhubung dengan masukan. Seperti pada Gambar 2 jika ada sumber panas yang lewat depan sensor, maka sensor akan mengaktifkan sel pertama dan sel kedua sehingga akan menghasilkan gelombang seperti dalam Gambar 3. Sinyal yang dihasilkan sensor PIR mempunyai frekuensi yang rendah yaitu $0,2-5 \mathrm{~Hz}$ [14]

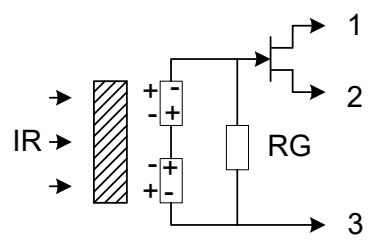

Gambar 2 Diagram internal rangkaian sensor PIR
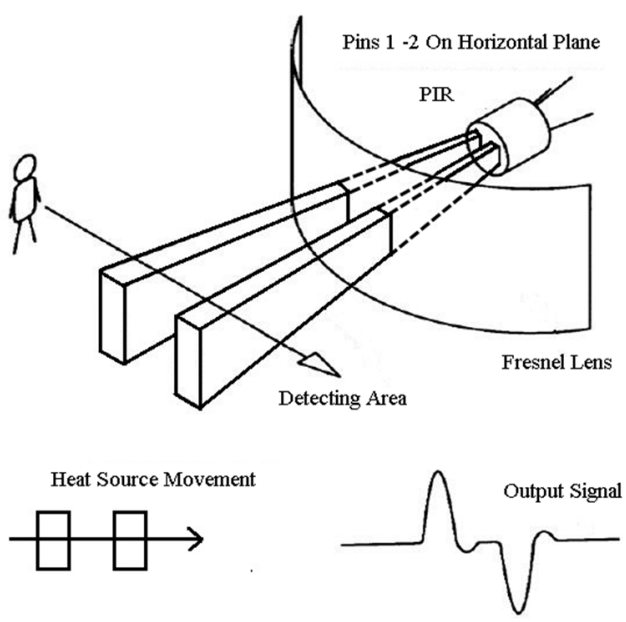

Gambar 3 Arah jangkauan gelombang sensor PIR

\section{Tinjauan Nilai Ekonomis}

\section{$3.1 \mathrm{kWh}$ dan Tarif Listrik per $\mathrm{kWh}$}

$\mathrm{kWh}$ merupakan satuan energi yang menyatakan besar energi dalam kilowatt dikali waktu dalam jam, misalnya sebuah beban listrik sebesar 100 watt dioperasikan selama satu jam maka besar energi adalah 0,1 kilowatt jam listrik.

Besar $\mathrm{kWh}$ yang diukur oleh alat ukur $\mathrm{kWh}$ meter merupakan besar pemakaian daya konsumen yang harus dibayar kepada pihak penyedia jasa listrik. Harga tarif listrik per $\mathrm{kWh}$ telah diatur oleh pemerintah sesuai dengan golongan tarif. Untuk golongan tarif P-2 /TM yang merupakan tarif tenaga listrik untuk keperluan kantor pemerintah berdasarkan peraturan Menteri Energi dan Sumber Daya Mineral nomor 31 tahun 2014 adalah dibagi dalam dua blok yaitu WBP (Waktu Beban Puncak) dan LWBP (Luar Waktu Beban Puncak) [15].

- $\mathrm{Blok} \mathrm{WBP}=\mathrm{K} \times 1115$

- Blok LWBP $=1115$

$\mathrm{K}$ adalah faktor perbandingan antara harga WBP dan LWBP $(1,4 \leq \mathrm{k} \leq 2)$

\subsection{Payback Period}

Payback period merupakan metode untuk mengukur seberapa cepat investasi bisa kembali [16], [17]. Masalah utama dari payback period adalah sulitnya menentukan periode payback maksimum yang diisyaratkan. Secara normatif, tidak ada pedoman yang bisa digunakan untuk menentukan periode payback maksimum. Suatu investasi dikatakan layak jika periode payback lebih pendek dari umur ekonomis aktiva.

Payback Period merupakan metode pelengkap penilaian investasi

$$
\text { Payback Period }=\mathrm{I} / \mathrm{Ab}
$$

Dimana: $\mathrm{I}=$ besarnya biaya investasi yang diperlukan $\mathrm{Ab}=$ manfaat bersih yang dapat diperoleh pada setiap tahunnya [18].

\section{Metode dan Perancangan}

\subsection{Diagram Sistem}

Gambar 4 berikut ini merupakan diagram blok dari perancangan sistem cerdas berbasis PLC 


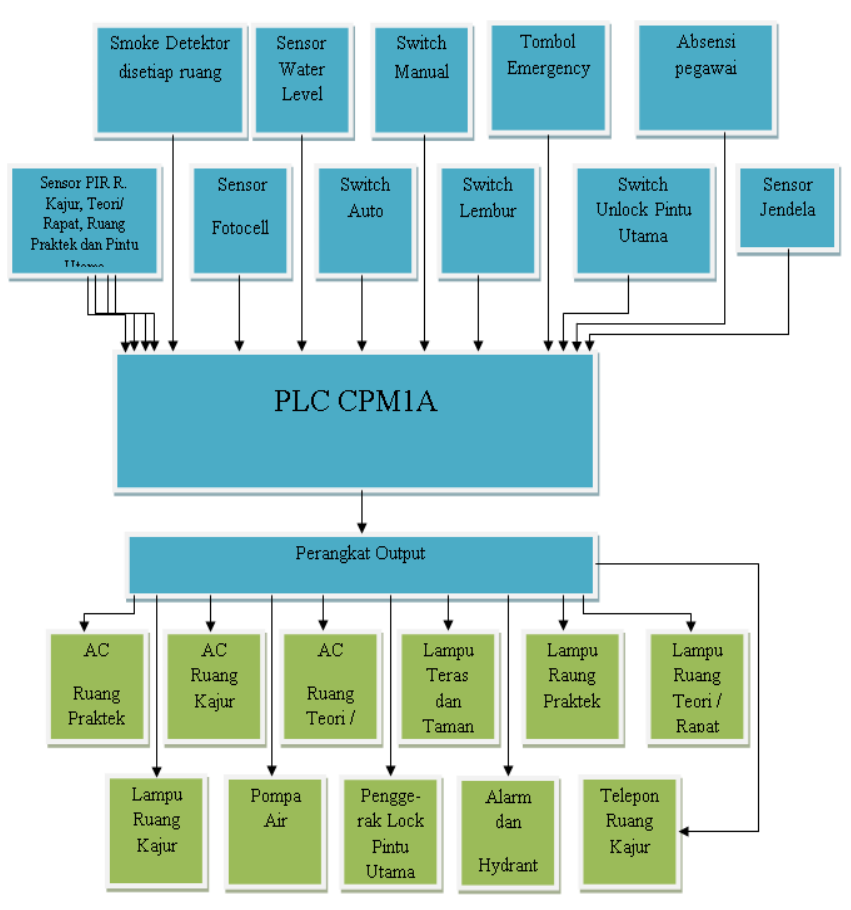

Gambar 4 Diagram blok sistem cerdas

Pada perancangan sistem cerdas ini perangkat yang digunakan terdiri dari PLC CPM1A sebagai kontrol utama, Untuk input digunakan Sensor Passive Infrared (PIR), Smoke Detekror, Sensor Fotocell, Sensor water kontrol, Switch Auto, Switch Manual, Switch Lembur, Tombol emergency, Switch Unlock Pintu Utama, absensi dan sensor jendela. Untuk output digunakan perangkat output. Perangkat output ini terdiri dari relai-relai yang difungsikan sebagai perantara/saklar yang mengaktifkan dan menonaktifkan tegangan tinggi $220 \mathrm{VAC}$ yang dikendalikan oleh PLC yang bekerja pada tegangan rendah 24 VDC.

Prinsip kerja sistem yaitu PLC menganalisa sinyal input kemudian mengatur keadaan output sesuai dengan kondisi yang telah ditentukan berdasarkan kontrol program sistem cerdas yang telah diprogram pada PLC.

\subsection{Perancangan Perangkat Keras Sistem Cerdas}

\subsubsection{Sensor Water Kontrol}

Sensor water kontrol merupakan perangkat input PLC dimana hubungan E1, E2 dan E3 pada rangkaian kontrol sistem cerdas terhadap input PLC ditentukan seperti pada tabel berikut.
Tabel 1 Hubungan Elektroda Terhadap Input PLC

\begin{tabular}{|c|c|}
\hline Elektroda & Input PLC \\
\hline E1 & 0.00 \\
E2 & 0.01 \\
E3 & 0 Volt \\
\hline
\end{tabular}

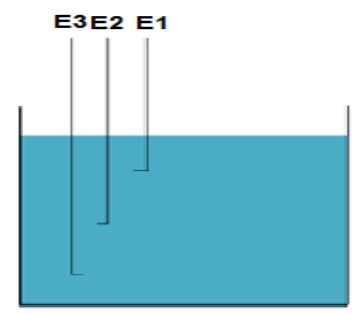

Gambar 5 Penempatan sensor water kontrol

Penempatan sensor water kontrol seperti ditunjukkan Gambar 5 dimana E1 adalah elektroda yang ditempatkan untuk mendeteksi level atas (air penuh) pada bak penampungan air. E2 adalah elektroda level bawah sedangkan E3 adalah elektroda sebagai grounding yaitu elektroda yang memberikan tegangan $0 \mathrm{~V}$ pada E1 dan E2.

Prinsip kerja sensor water kontrol apabila air dalam posisi penuh maka kedua elektroda E1 dan E2 mendapatkan tegangan 0 Volt dari E3 yang dihantarkan melalui air sedangkan jika E1 dan E2 tidak mendapatkan tegangan 0 volt dari E3 maka posisi bak penampungan dalam keadaan kosong atau harus diisi air kembali. Tegangan 0 Volt pada E1 dan E2 yang dihantarkan melalui air ini akan diinputkan ke input PLC dengan alamat seperti dalam Tabel 1 diatas. Dipasang tegangan 0 Volt pada E3 agar lebih aman jika manusia menyentuh air dalam bak penampungan disamping itu PLC juga mendeteksi adanya input jika diberi tegangan 0 Volt pada kaki input

\subsubsection{Tombol Tekan}

Pada perancangan sistem cerdas tombol tekan digunakan sebagai tombol emergency, tombol lembur dan tombol unlock pintu utama yang dihubungkan pada input PLC. Prinsip kerja tombol tekan ini apabila ditekan kontak akan terhubung (tertutup) jika dilepas kontak akan terputus (terbuka). Pemasangan tombol tekan pada input PLC untuk memberikan tegangan $0 \mathrm{~V}$ di input PLC sama halnya seperti pada pemasangan sensor water kontrol dimana PLC mendeteksi adanya input jika diberi tegangan 0 Volt pada kaki input PLC.

Hubungan tombol emergency, tombol lembur dan tombol unlock pintu utama ditentukan seperti 
pada Tabel 2 berikut yang dimaksudkan agar input teralokasi dengan tepat dan juga memudahkan dalam pemograman nantinya.

Tabel 2 Hubungan tombol emergency, tombol lembur dan tombol unlock pintu utama

\begin{tabular}{|c|c|}
\hline Tombol Tekan & Input PLC \\
\hline Emergency & 0.02 \\
Lembur & 0.03 \\
Unlock Pintu Utama & 0.04 \\
\hline
\end{tabular}

\subsubsection{Sensor Fotocell}

Fotocell adalah rangkaian elektronik yang terdiri dari LDR (Light Dependent Resistor) seperti pada Gambar 6. Prinsip kerja resistor dengan sensitivitas cahaya adalah apabila kondisi gelap nilai resistansi akan menjadi rendah sehingga arus mengalir dan beban lampu yang dihubung pada sensor ini akan menyala. Pada kondisi terang, nilai resistansi menjadi tinggi sehingga arus tidak dapat mengalir dan lampu akan menjadi padam.

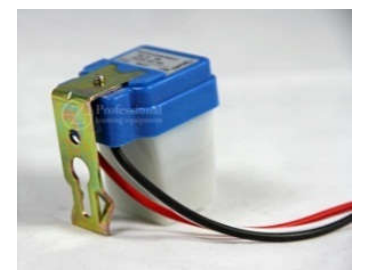

Gambar 6 Fotocell [19]

Tegangan keluaran sensor fotocell yang digunakan adalah 220 VAC sehingga keluaran sensor ini tidak bisa langsung dihubungkan dengan input PLC. Pada perancangan keluaran sensor fotocell dihubungkan dengan sebuah relai 220 VAC seperti ditunjukkan pada Gambar 7, dimana sensor ini akan menggerakkan relai, anak kontak relai yang memberikan tegangan 0 volt pada input PLC dengan alamat 0.05. Berikut gambar rangkaian hubungan relai dengan sensor fotocell.

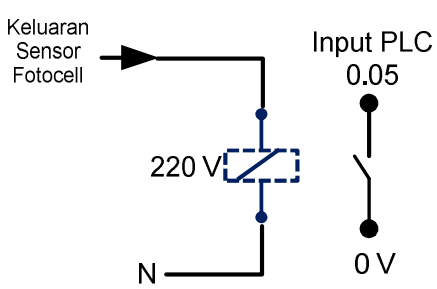

Gambar 7 Rangkaian hubungan relai dengan sensor fotocell

\subsubsection{Sensor Passive Infrared (PIR) dan Smoke Detektor}

Tegangan keluaran sensor Passive Infrared (PIR) yang digunakan adalah 5 VDC sehingga keluaran sensor ini tidak dapat langsung dihubung ke input PLC dikarenakan input PLC mendeteksi tegangan $0 \mathrm{~V}$ sehingga pada perancangan keluaran sensor ini dibuhungkan ke relai 5 VDC. Prinsip kerjanya adalah jika sensor Passive Infrared (PIR) bekerja maka relai 5 VDC akan bekerja dan anak kontak relai tersebut akan menghubungkan tegangan 0 Volt pada input PLC.

Sedangkan tegangan keluaran dari smoke detektor adalah 24 VDC, sama halnya dengan sensor Passive Infrared (PIR) dimana keluarannya tidak dapat langsung dihubung ke input PLC tetapi harus melalui perantara relai. Relai yang digunakan untuk keluaran smoke detektor adalah 24 VDC. Prinsip kerjanya juga sama dengan kerja relai pada keluaran Passive Infrared (PIR).

Pada gedung workshop Otomasi Industri smoke detektor dihubung paralel untuk seluruh ruangan sehingga hanya membutuhkan 1 input PLC sedangkan sensor Passive Infrared (PIR) tidak dihubung secara paralel tetapi dipasang pada pintu ruang kajur, pintu ruang teori/rapat, ruang praktek dan pintu utama, sensor Passive Infrared (PIR) dipasang tepat diatas pintu masuk agar dapat mendeteksi pergerakan orang yang masuk ruangan. Jenis sensor Passive Infrared (PIR) yang digunakan pada perancangan adalah HC-SR501 PIR Motion Detector yang mempunyai range sensing $120^{\circ}$ dengan jarak jangkau 7 meter. Berikut Tabel 3 yang menunjukkan hubungan sensor smoke detektor dan sensor Passive Infrared (PIR) terhadap input PLC.

Tabel 3 hubungan sensor smoke detektor dan sensor Passive Infrared (PIR) terhadap input PLC

\begin{tabular}{|c|c|}
\hline Sensor & Input PLC \\
\hline Smoke Detektor & 0.06 \\
Sensor PIR Ruang Kajur & 0.07 \\
Sensor PIR Ruang Teori/Rapat & 0.08 \\
Sensor PIR Ruang Praktek & 0.09 \\
Sensor PIR Pintu Utama Dalam & 0.10 \\
\hline
\end{tabular}

Gambar 8, Gambar 9 dan Gambar 10 berikut rancangan rangkaian hubungan relai dengan smoke detektor dan sensor Passive Infrared (PIR). 


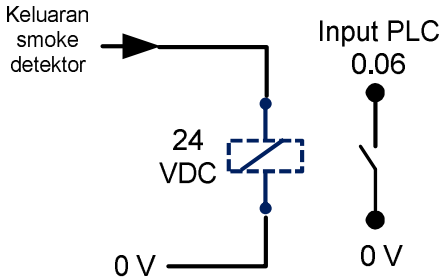

Gambar 8 Rangkaian hubungan relai dan smoke detektor
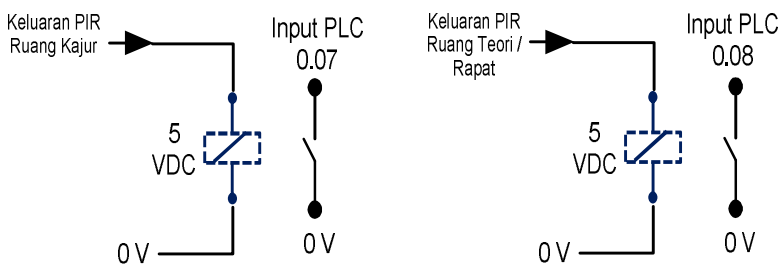

Gambar 9 Rangkaian hubungan relai dengan sensor PIR untuk ruang kajur dan ruang teori/rapat
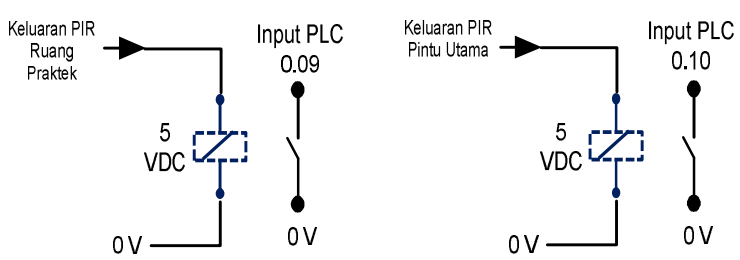

Gambar 10 Rangkaian hubungan relai dengan sensor PIR untuk ruang praktek dan pintu utama dalam

\subsubsection{Switch Manual / Auto}

Selector switch digunankan untuk switch manual / auto. Sistem cerdas dirancang untuk dapat bekerja manual maupun auto, kondisi bekerja manual bertujuan jika pada kondisi tertentu diperlukan sistem harus bekerja secara manual seperti pada saat perawatan sistem kontrol auto. Untuk kondisi bekerja manual semua peralatan listrik dikontrol seperti biasanya yaitu melalui saklar atau remot kontrol untuk mengoperasikan AC. Pada sistem juga dilengkapi switch auto ini bertujuan agar dapat kembali ke kondisi bekerja secara auto setelah masa perawatan selesai dilaksanakan.

Switch manual / auto dihubung dengan dua input PLC dengan alamat 0.11 dan 1.00 masingmasing untuk manual dan auto seperti ditunjukkan pada Gambar 11.

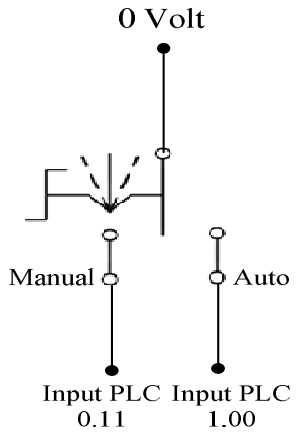

Gambar 11 rangkaian untuk switch manual / auto

\subsubsection{Sensor Jendela}

Untuk sensor jendela digunakan limit switch yang ditempatkan disetiap jendela dan dihubung secara seri sehingga hanya membutuhkan satu alamat input PLC seperti ditunjukkan pada Gambar 12.

Dipasang hubungan seri agar dapat diketahui apakah semua jendela dalam kondisi tertutup semua atau ada jendela yang masih terbuka. Prinsip kerja sensor jendela, jika posisi jendela tertutup maka limit switch akan tertekan oleh jendela. Berikut gambar perancangan rangkaian sensor jendela.

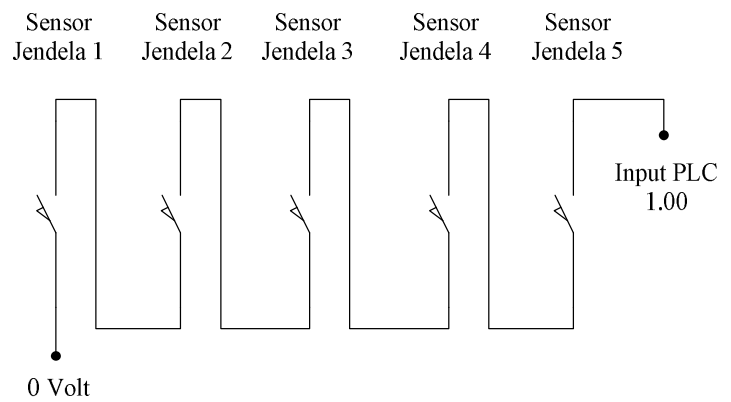

Gambar 12 Rangkaian sensor jendela

\subsubsection{Absensi Pegawai}

Sistem cerdas dirancang agar dapat bekerja setiap hari kerja setelah pegawai melakukan absensi. Prinsip kerjanya, sistem akan mengunlock pintu utama selama rentang waku jam kerja jika salah satu dari pegawai telah melakukan absensi dan sembarang orang hadir didepan pintu utama. Alat Absensi dihubung dengan input PLC melalui komputer PC dan perantara relai seperti dapat dilihat pada Gambar 14. Setiap komputer menyediakan port USB yang dapat dimanfaatkan sebagai media komunikasi antar komputer dengan peralatan di luar komputer dengan menggunakan 
software dalam hal ini menggunakan software khusus absensi. Keluaran USB dihubungkan dengan relai 5 Volt sehingga jika pegawai yang melakukan absensi maka relai akan bekerja yang menghubungkan tegangan 0 volt ke input PLC dengan alamat 1.01. relai ini akan terus bekerja selama rentang waktu jam kerja.

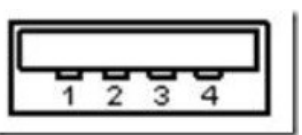

Gambar 13 Port USB

Tabel 4 Fungsi PIN pada Port USB

\begin{tabular}{|c|c|}
\hline PIN & FUNGSI \\
\hline 1 & V Bus ( 5 volt ) \\
2 & D- \\
3 & D+ \\
4 & Ground \\
\hline
\end{tabular}

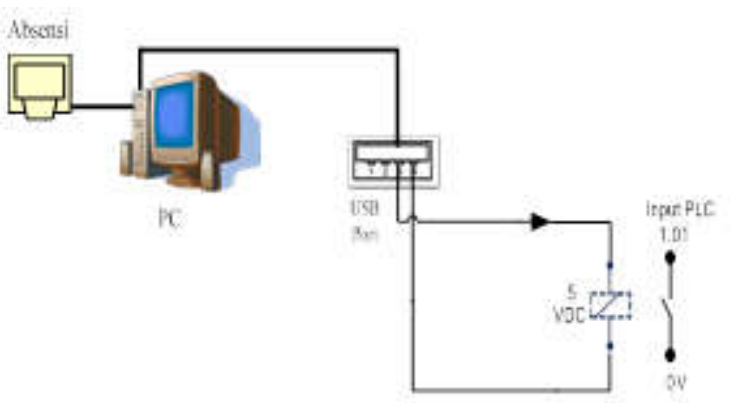

Gambar 14 Hubungan Alat Absensi dengan input PLC melalui komputer PC dan perantara relai

\subsubsection{Perangkat Output}

Beban AC, lampu, motor pompa dan alarm dikendalikan oleh PLC melalui perangkat ouput. Perangkat output terdiri dari relai-relai 24 VDC, penggunaan relai adalah sebagai saklar tegangan tinggi yaitu $220 \mathrm{VAC}$ yang dikendalikan dengan tegangan rendah yang merupakan tegangan ouput PLC 24 VDC. Berikut perancangan perangkat output untuk salah satu beban seperti pada Gambar 15.

Perangkat output untuk beban yang lain sama seperti perangkat output pada Gambar 15, yang membedakan adalah alamat output PLC yang diatur sesuai perancangan seperti dalam Tabel 5.

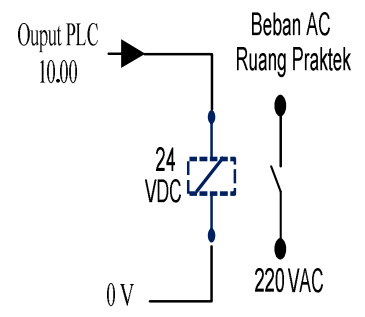

Gambar 15 Perangkat output untuk mengendalikan beban AC ruang praktek

Tabel 5 Tabel pengaturan output PLC untuk pengendalian beban pada sistem cerdas

\begin{tabular}{|c|c|}
\hline Alamat Output PLC & Beban \\
\hline 10.00 & AC Ruang Praktek \\
10.01 & AC Ruang Kajur \\
10.02 & AC Ruang Teori / Rapat \\
10.03 & Lampu Teras dan Taman \\
10.04 & Lampu Raung Praktek \\
10.05 & Lampu Ruang Teori / Rapat \\
10.06 & Lampu Ruang Kajur \\
10.07 & Pompa Air \\
11.00 & Motor Lock Pintu Utama \\
11.01 & Alarm dan Hydrant \\
11.02 & Telepon Ruang Kajur \\
\hline
\end{tabular}

\subsection{Perancangan Perangkat Lunak}

Perancangan perangkat lunak diperlukan agar mempermudah dalam membuat program. Perangkat lunak yang dibuat dirancang dalam bentuk diagram alir (flow chart) sedangkan program menggunakan ladder diagram.

Sistem cerdas dirancang agar dapat juga bekerja secara manual, ini bertujuan jika pada kondisi tertentu diperlukan sistem harus bekerja secara manual seperti pada saat perawatan sistem kontrol operasi auto. Untuk operasi manual semua peralatan listrik dikontrol seperti biasanya yaitu melalui saklar atau remot kontrol. Pada operasi auto, PLC akan terus memantau input dan kemudian mengatur output sesuai kondisi yang telah ditentukan pada program. Pintu utama akan unlock setiap hari kerja setelah salah satu pegawai melakukan absensi dan hadir didepan pintu utama, pada pintu utama ditempatkan sensor Passive Infrared (PIR), pintu tidak akan unlock jika pegawai belum hadir didepan pintu walaupun absensi telah dilaksanakan. Untuk kondisi darurat jika pegawai harus masuk ke workshop disaat bukan hari kerja maka pegawai harus menekan tombol emergency yang ditempatkan dikantor utama untuk dapat meng-unlock pintu utama workshop dan menekan tombol emergency kembali untuk men-lock pintu utama. 
Algoritma utama sistem ditunjukkan pada Gambar 16. Sistem dapat bekerja secara auto ataupun manual. Kondisi lembur aktif jika tombol lembur ditekan, sesuai pada algoritma di Gambar 17. Pengendalian peralatan pada ruangan kajur ataupun rapat memiliki algoritma yang mirip seperti pada Gambar 18. Lampu ruang kerja akan aktif menggunakan sensor photocell seperti pada
Gambar 19. Gambar 20 menunjukkan algoritma pengendalian pompa air. Pengendalian peralatan pada saat kondisi lembur terdapat pada gambar 21. Sedangkan untuk deteksi asap dan keamanan gedung menggunakan alarm dikendalikan berdasarkan algoritma pada gambar 22 dan gambar 23 .

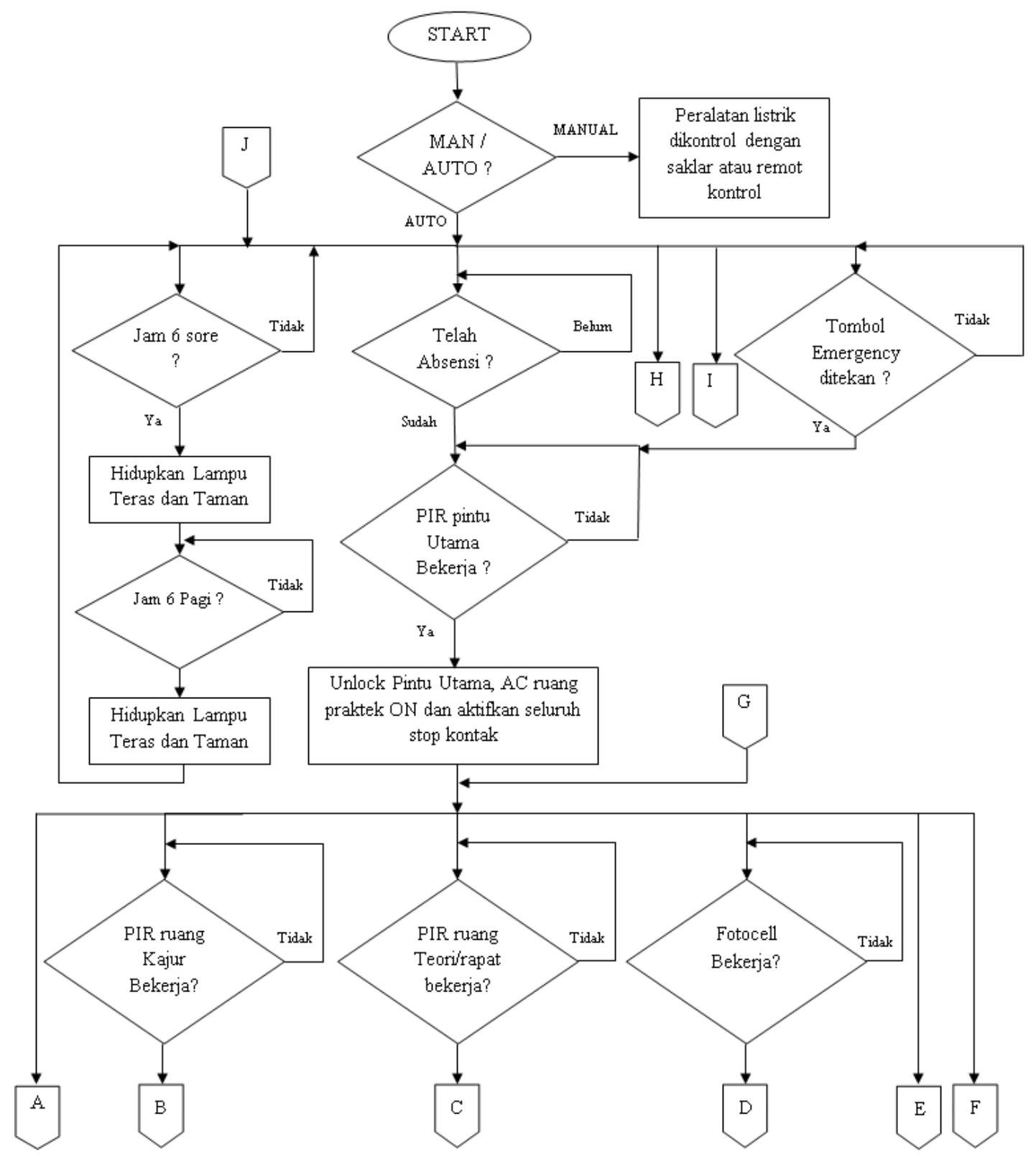

Gambar 16 Algoritma utama 


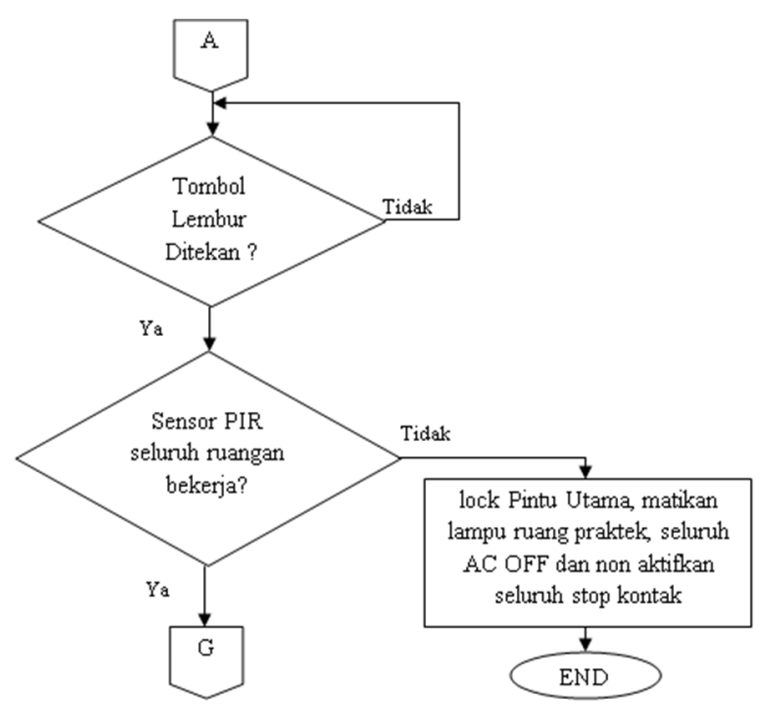

Gambar 17 kondisi lembur

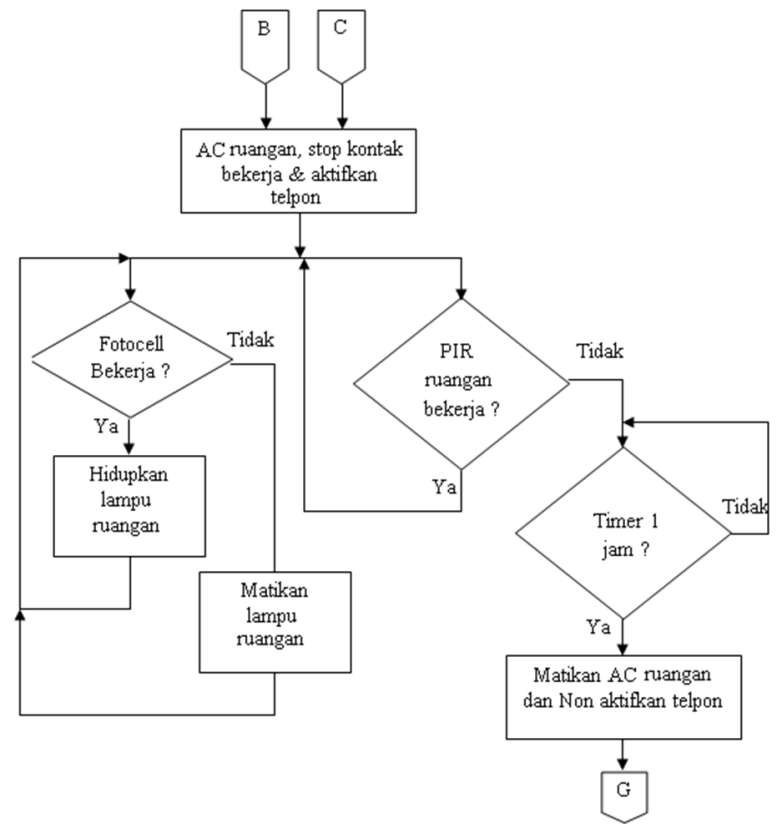

Gambar 18 Ruang Kajur/Rapat

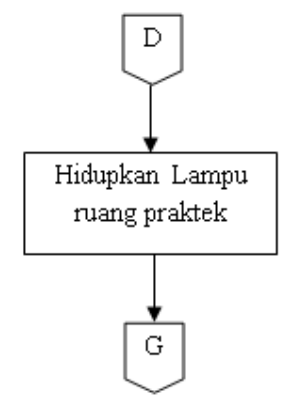

Gambar 19 Flow chart rosedur kerja lampu ruang praktek

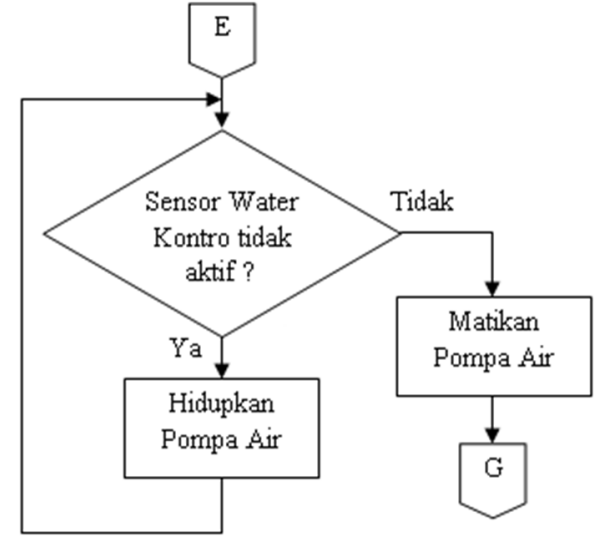

Gambar 20 Flow rosedur kerja untuk Pompa Air

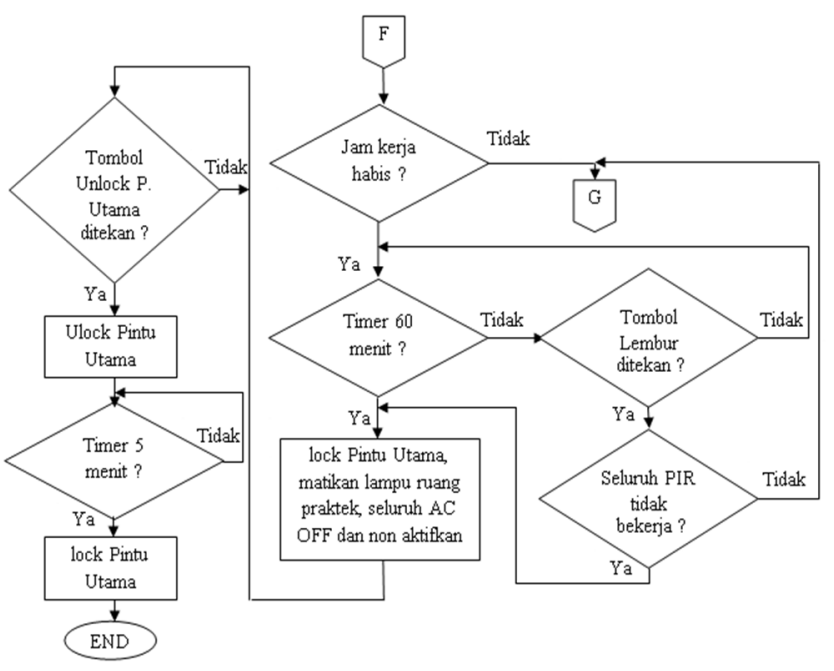

Gambar 21 Flow Chart prosedur kerja untuk jam kerja dan lembur

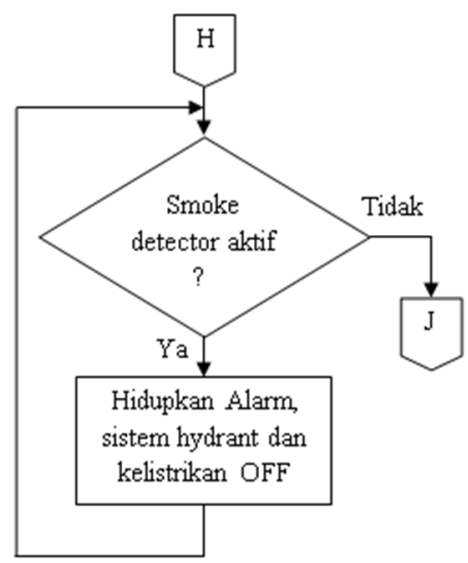

Gambar 22 Flow Chart prosedur kerja untuk smoke detector 


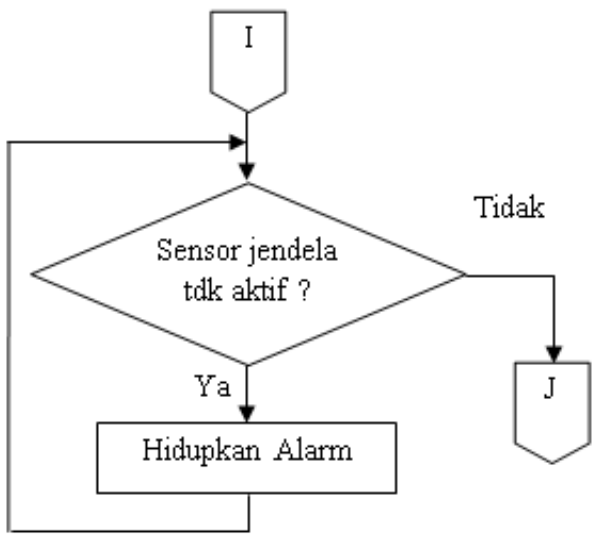

Gambar 23 Flow Chart prosedur kerja untuk sensor jendela

\section{Hasil dan Pembahasan}

Pengujian dilakukan setelah dilakukan instalasi seperti ditunjukkan pada Gambar 24. pemrograman menggunakan ladder logic dibangun sesuai algoritma yang dirancang. Bagian program dari algoritma program utama melalui prosedur absensi diperlihatkan pada Gambar 25.

Sistem cerdas ini adalah sistem kontrol ON/OFF untuk mengatur pengoperasian beban listrik yang ada di workshop otomasi industri sesuai dengan kebutuhan agar dapat menghemat pemakaian energi listrik. Dalam pengujian hanya dilakukan pengamatan ON/OFF beban listrik, dimana hasil yang didapat sesuai dengan perancangan alur kerja sistem.

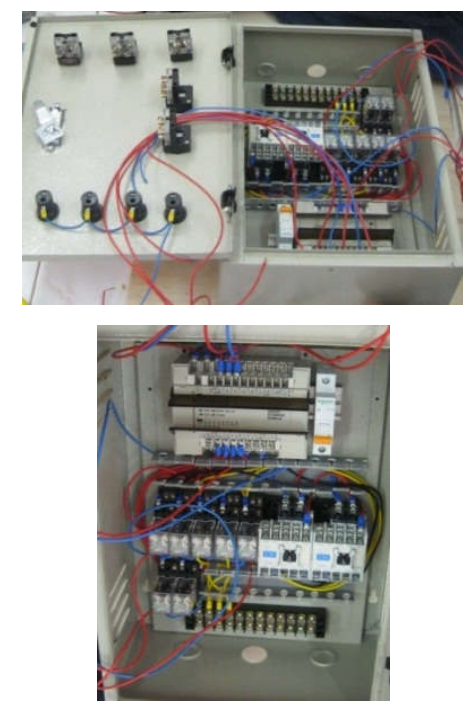

Gambar 24 Hasil perakitan panel sistem cerdas untuk Workshop Otomasi Industri Balai Latihan Kerja

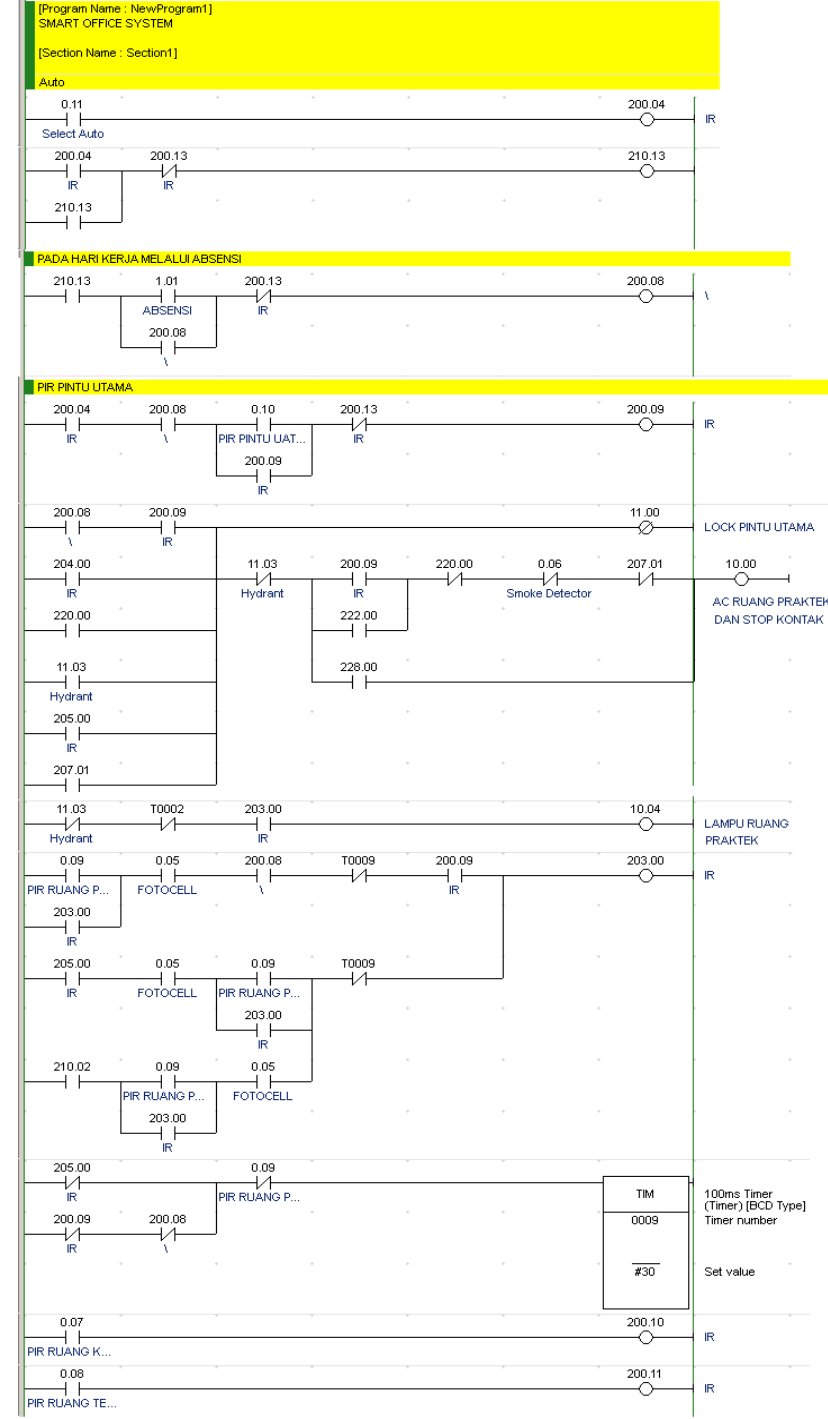

Gambar 25 Bagian program ladder diagram dari flow chart program utama melalui prosedur absensi

Setelah diimplemtasikan sistem cerdas, jam kerja setiap jenis beban listrik lebih kecil jika dibandingkan dengan sebelum diimplemtasikan sistem cerdas seperti pada Tabel 6, jumlah jam kerja setiap beban listrik pada tabel tersebut merupakan rata-rata dari jam kerja yang diperoleh setelah dilakukan pengamatan selama 14 hari atau 2 minggu pada setiap jenis beban listrik 
Tabel 6 hasil pengamatan jumlah rata-rata jam kerja beban listrik dalam sehari sebelum dan setelah implementasi sistem cerdas

\begin{tabular}{|c|c|c|c|c|c|}
\hline Jenis Beban Listrik & Jumlah Unit Beban & Daya (Watt) & Total Daya (Watt) & $\begin{array}{c}\text { Jumlah Jam Kerja } \\
\text { (Jam) Sebelum } \\
\text { Implementasi } \\
\text { Sistem Cerdas }\end{array}$ & $\begin{array}{c}\text { Jumlah Jam Kerja } \\
\text { (Jam) Setelah } \\
\text { Implementasi } \\
\text { Sistem Cerdas }\end{array}$ \\
\hline AC Ruang Praktek & 2 & 1492 & 2984 & 9 & 7 \\
AC Ruang Kajur & 1 & 1119 & 1119 & 9 & 2 \\
AC Ruang Teori & 1 & 1492 & 1492 & 9 & 2 \\
Lampu Teras dan Taman & 3 & 100 & 300 & 14 & 2 \\
Lampu Ruang Praktek & 6 & 32 & 192 & 9 & 2 \\
Lampu Ruang Teori & 4 & 32 & 128 & 9 & 1 \\
Lampu Ruang Kajur & 1 & 32 & 32 & $8(5$ hari/ & $1(5$ hari/ \\
Pompa Air & 1 & 750 & 750 & seminggu) \\
\hline
\end{tabular}

Sebelum diimplementasikan sistem cerdas jumlah jam kerja dari setiap jenis beban adalah 9 jam kecuali untuk jenis beban lampu teras/taman dan pompa air. Untuk lampu teras dan taman beroperasi selama 14 jam karena lampu dihidupkan pada panel utama kantor oleh petugas sekitar jam 6 sore dan baru dipadamkan pada jam 8 pagi disaat mulai aktivitas kantor sedangkan pompa air beroperasi 4 jam untuk mengisi penuh bak penampungan dari kondisi kosong. Dalam seminggu (hari kantor/hari kerja) pompa air beroperasi dua kali sehingga total jam kerja menjadi 8 jam. Semua beban listrik dikontrol pada panel induk oleh petugas (listrik dipadamkan jam 5 sore oleh petugas).

Setelah diimplementasikan sistem cerdas jumlah jam kerja dari setiap jenis beban akan berkurang seperti dalam Tabel 6 dikarenakan sistem bekerja secara otomatis mengontrol atau mengatur penggunaan beban listrik sesuai dengan kebutuhan, contohnya seperti pompa air dalam seminggu (hari kantor/hari kerja) hanya bekerja 1 jam, ini jauh sangat bekurang dari jam kerjanya sebelum diimplementasikan sistem cerdas.

Dari jumlah jam kerja setiap beban listrik tersebut diperoleh jumlah daya (Kwh) yang dipakai per hari seperti ditunjukkan pada Tabel 7. Jumlah penggunaan daya per hari sebelum diimplemtasikan sistem cerdas ini adalah 58,93 Kwh tetapi setelah diimplentasikan sistem cerdas jumlah penggunaan daya turun menjadi 30,53 Kwh, ini menunjukkan bahwa dengan mengontrol penggunaan beban listrik sesuai dengan kebutuhan secara otomatis dengan sistem cerdas akan diperoleh penghematan daya terpakai.

Untuk total pengeluaran biaya harian diperoleh dari total Kwh terpakai per hari. Harga per $\mathrm{kWh}$ pada perhitungan dalam Tabel 7 diambil untuk golongan tarif P-2 /TM yang merupakan tarif tenaga listrik untuk keperluan kantor pemerintah berdasarkan peraturan Menteri Energi dan Sumber Daya Mineral nomor 31 tahun 2014. Tarif diambil pada blok LWBP (Luar Waktu Beban Puncak) karena beban dioperasikan siang hari yang merupakan luar waktu beban puncak.

Jika dibandingkan hasil perhitungan total pengeluaran biaya harian pada Tabel 7 , maka total pengeluaran harian setelah diimplentasikan sistem cerdas diperoleh lebih kecil yaitu sebesar Rp. 34.043,18 dari sebelum diimplementasikan sistem cerdas yaitu sebasar Rp. 65.706,95.

Jika dihitung pengeluaran dalam tiga puluh hari (satu bulan) untuk pembayaran rekening listrik setelah diimplementasikan sistem cerdas adalah sebesar Rp. 1.021.295,- sedangkan besar pengeluaran sebelumnya adalah sebesar Rp.1.971.208,-. Sehingga dengan diimplementasikan sistem cerdas dapat menghemat biaya pengeluaran pembayaran rekening listrik per bulan adalah sebesar Rp.949.913,-, dan dalam satu tahun besar penghematan Rp.11.398.962,-.

Besar total biaya investasi untuk pemasangan sistem cerdas ini sebesar Rp. 6.350.000,-. Jika dibandingkan dengan besar 
Tabel $7 \mathrm{Kwh}$ terpakai dan total pengeluaran biaya harian sebelum dan setelah implementasi sistem cerdas

\begin{tabular}{|c|c|c|c|c|c|c|c|c|}
\hline $\begin{array}{l}\text { Jenis Beban } \\
\text { Listrik }\end{array}$ & $\begin{array}{l}\text { Total } \\
\text { Daya }\end{array}$ & $\begin{array}{c}\text { Jumlah Jam } \\
\text { Kerja (Jam) } \\
\text { Sebelum } \\
\text { diimplementasi } \\
\text { Sistem Cerdas } \\
\end{array}$ & $\begin{array}{c}\text { Jumlah Jam } \\
\text { Kerja (Jam) } \\
\text { Setelah } \\
\text { diimplementasi } \\
\text { Sistem Cerdas } \\
\end{array}$ & $\begin{array}{c}\text { Jumlah } \\
\text { kWh / } \\
\text { Hari }\end{array}$ & $\begin{array}{c}\text { Jumlah } \\
\text { kWh / } \\
\text { Hari }\end{array}$ & $\begin{array}{l}\text { Harga per } \\
\text { kWh (Rp) }\end{array}$ & $\begin{array}{c}\text { Besar } \\
\text { Pengeluaran } \\
\text { Biaya (Rp) }\end{array}$ & $\begin{array}{c}\text { Besar } \\
\text { Pengeluaran } \\
\text { Biaya (Rp) }\end{array}$ \\
\hline $\begin{array}{l}\text { AC Ruang } \\
\text { Praktek }\end{array}$ & 2984 & 9 & 7 & 26,86 & 20,89 & & $29.948,9$ & $23.292,35$ \\
\hline $\begin{array}{l}\text { AC Ruang } \\
\text { Kajur }\end{array}$ & 1119 & 9 & 2 & 10,07 & 2,24 & & $11.228,05$ & $2.497,6$ \\
\hline AC Ruang Teori & 1492 & 9 & 2 & 13,43 & 2,98 & & $14.974,45$ & $3.322,7$ \\
\hline $\begin{array}{l}\text { Lampu Teras } \\
\text { dan Taman }\end{array}$ & 300 & 14 & 12 & 4,20 & 3,60 & & $4.683,00$ & 4.014 \\
\hline $\begin{array}{c}\text { Lampu Ruang } \\
\text { Praktek }\end{array}$ & 192 & 9 & 2 & 1,73 & 0,38 & 1.115 & $1.928,95$ & 423,7 \\
\hline $\begin{array}{c}\text { Lampu Ruang } \\
\text { Teori }\end{array}$ & 128 & 9 & 2 & 1,15 & 0,26 & & $1.282,25$ & 289,9 \\
\hline $\begin{array}{c}\text { Lampu Ruang } \\
\text { Kajur }\end{array}$ & 32 & 9 & 1 & 0,29 & 0,032 & & 323,35 & 35,68 \\
\hline Pompa Air & 750 & $\begin{array}{l}8 \text { ( } 5 \text { hari/ } \\
\text { seminggu }\end{array}$ & $\begin{array}{c}1 \text { ( } 5 \text { hari/ } \\
\text { seminggu })\end{array}$ & 1,20 & 0,15 & & 1.338 & 167,25 \\
\hline \multicolumn{4}{|c|}{ Jumlah Total Kwh Per hari } & 58,93 & $\mathbf{3 0 , 5 3}$ & $\begin{array}{c}\text { Jumlah } \\
\text { Total } \\
\text { pengeluar } \\
\text { an biaya }\end{array}$ & $65.706,95$ & 34.043,18 \\
\hline
\end{tabular}

biaya penghematan yang diperoleh, maka payback period kurang dari 7 bulan. Dapat disimpulkan bahwa investasi yang dikeluarkan dalam rangka memperoleh penghematan penggunaan daya listrik pada gedung workshop otomasi industri Balai Latihan Kerja Banda Aceh layak dilaksanakan dikarenakan periode payback yang diperole lebih pendek dari umur ekonomis aktiva.

Dengan penggunaan PLC sebagai pengontrol maka dipastikan tidak ada biaya pengeluran untuk pemeliharaan dalam waktu satu tahun asalkan penempatan panel sistem cerdas ini pada suhu sesuai dengan suhu kerja yang diperbolehkan oleh pabrik pembuat PLC. Sedangkan untuk komponen perangkat input dan output dari spesifikasi yang diperoleh dari datasheet mempunyai life time selama 3 tahun. Sehingga dengan diimplementasikan sistem cerdas penghematan pemakaian energi listrik yang dicanangkan dalam peraturan Menteri ESDM No. 13 tahun 2012 dapat direalisasikan.

\section{Kesimpulan}

Dengan diimplementasikan sistem cerdas pada gedung workshop otomasi industri Balai Latihan Kerja Banda Aceh, pengunaan energi listrik dapat dikendalikan secara efisien sehingga diperoleh penghematan pengeluaran pembayaran rekening listrik sesuai yang diharapkan dalam peraturan pemerintah. Saran lebih lanjut adalah mengembangkan sistem cerdas ini dengan menambah pengontrol yang berbasis pada internet of think ( IOT) sehingga dapat dimonitor dan dikendalikan jarak jauh jika diperlukan.

\section{Daftar Pustaka}

[1] M. E. dan S. D. M. R. Indonesia, "Peraturan Pemerintah tentang Penghematan Pemakaian Tenaga Listrik," Republik Indonesia, 2012.

[2] C. M. Lin and M. T. Chen, "Design and implementation of a smart home energy saving system with active loading feature identification and power management," 2017 IEEE 3rd Int. Futur. Energy Electron. Conf. ECCE Asia, IFEEC ECCE Asia 2017, pp. 739-742, 2017.

[3] H. Lee, W. Park, and I. Lee, "A Home Energy Management System for EnergyEfficient Smart Homes," IEEE Int. Conf. Comput. Sci. Comput. Intell., pp. 626629, 2014. 
[4] A. S. Shah, H. Nasir, M. Fayaz, A. Lajis, and A. Shah, "A review on energy consumption optimization techniques in IoT based smart building environments," Inf., vol. 10, no. 3, 2019.

[5] K. R. Wagiman and M. N. Abdullah, "Intelligent lighting control system for energy savings in office building," Indones. J. Electr. Eng. Comput. Sci., vol. 11, no. 1, pp. 195-202, 2018.

[6] M. Muharam, M. Latif, and M. Saputra, "Sistem Kendali Jarak Jauh Berbasis Web untuk Sistem Rumah Pintar," J. Nas. Tek. Elektro, vol. 7, no. 3, p. 203, 2018.

[7] D. Kurnianto, A. M. Hadi, and E. Wahyudi, "Perancangan Sistem Kendali Otomatis pada Smart Home menggunakan Modul Arduino Uno," $J$. Nas. Tek. Elektro, vol. 5, no. 2, p. 260, 2016.

[8] N. Skeledžija, J. Ćesić, E. Kočo, V. Bachler, H. N. Vučemilo, and H. Džapo, "Smart home automation system for energy efficient housing," IEEE 37th Int. Conv. Inf. Commun. Technol. Electron. Microelectron. MIPRO 2014 - Proc., no. May, pp. 166-171, 2014.

[9] K. Wibowo, "Feasibility Study And Investment Analysis Of Mix Use Sentraland Semarang," no. C, pp. 718724, 2017.

[10] M. C. Freire, C. Q. Pica, A. L. Da Silva, and M. A. I. Martins, "Analysis of relevant technical and economic aspects to support the choice of feasible locations for photovoltaic power plants in Brazil," 2015 IEEE PES Innov. Smart Grid Technol. Lat. Am. ISGT LATAM 2015, pp. 258-263, 2016.

[11] Murtono Suhartono, Memasang Instalsi PLC. Jakarta: Kementerian Tenaga Kerja dan Transmigrasi RI, 2012.

[12] D. A. Kaylo, Programmable ControllersSysmac CPMIA Programmable Controller. Omron, 2007.

[13] S. Aulia, "Sistem Keamanan Berbasis Alarm Ip Camera Dengan Passive Infrared Receiver ( Pir ) Sensor Dan Sms Gateway Ip-Based Security Alarm System With Camera Passive Infrared Receiver ( PIR ) Sensor," Fak. Ilmu
Telkom, Univ. Telkom, pp. 312-320, 2016.

[14] Anonymous, "Datasheet PIR Sensor Module." [Online]. Available: http://alldatasheet.com. [Accessed: 02Jun-2016].

[15] Anonymous, Peraturan Pemerintah tentang Tarif Tenaga Listrik Yang Disediakan Oleh Perusahaan Perseroan (Persero) PT Perusahaan Listrik Negara. Jakarta.

[16] M. S. Wilujeng, Titin Amrih Riyadi, Slamet Ridwan, "Analisis Swot Dan Aspek Keuangan Studi Kelayakan Investasi Pengembangan Rumah Sakit Umum Wonolangan Probolinggo," vol. 4, no. September, 2019.

[17] E. Susilowati and H. Kurniati, "Analisis Kelayakan dan Sensitivitas: Studi Kasus Industri Kecil Tempe Kopti Semanan, Kecamatan Kalideres, Jakarta Barat," BISMA (Bisnis dan Manajemen), vol. 10, no. 2, p. 102, 2018.

[18] Syukriyadin, "Manajemen Studi Kelayakan Investasi Proyek," Universitas Syiah Kuala Banda Aceh, 2015.

[19] F. Setiawan, "Sensor Optic - Photo Cell." [Online]. Available: http://fajarsetiawan1994.blogspot.co.id/2 014/03/sensor-optic-photo-cell.html. [Accessed: 02-Jun-2016].

\section{Biodata Penulis}

\section{Muhammad Yusuf}

Balai Latihan Kerja Banda Aceh Kementerian Ketenagakerjaan RI, Jabatan Intruktur Muda di Kejuruan Listrik Sub Kejuruan Otomasi Industri

\section{Ira Devi Sara}

Magister Teknik Elektro, Fakultas Teknik, Universitas Syiah Kuala, Dosen Bidang Studi Teknik Listrik dan Energi Terbarukan 